\title{
Ультразвукова діагностика невідкладних станів при гострій серцевій недостатності
}

\author{
Колтунова Г. Б., Бешляга І. В., Бешляга В. М. \\ ДУ «Національний інститут серцево-судинної хірургії імені М. М. Амосова НАМН» (Київ)
}

\begin{abstract}
Проведення ехокардіографічного дослідження все частіше рекомендується для діагностики та оцінки невідкладних станів пацієнтів при гострій серцевій недостатності. Розвиток ультразвукових технологій зумовив упровадження цього дослідження в практику не тільки кардіологів, а й лікарів-анестезіологів у відділеннях реанімації та інтенсивної терапії. Результати ехокардіографічного обстеження покращують точність ранньої діагностики, тактику ведення та моніторинг результатів запропонованого лікування у хворих на гостру серцеву недостатність. Використання цілеспрямованої ехокардіографії лікарями-інтенсивістами для лікування гострої серцевої недостатності зміцнює традиційну модель медичної допомоги.
\end{abstract}

Ключові слова: невідкладні стани, гостра серцева недостатність, цілеспрямована ехокардіографія.

Серцева недостатність - головна причина звернення за медичною допомогою в більш ніж 1 млн. випадків на рік у США, при цьому частка повторної госпіталізації протягом наступного місяця становить 25\% випадків, а летальність сягає 10-20\% протягом 6 місяців після виписки $[1,2]$. Гостра серцева недостатність $(Г С Н)$ може виступати як новий діагноз або як декомпенсація хронічної серцевої недостатності. Відповідно до європейських даних, приблизно 50\% цих пацієнтів будуть повторно госпіталізовані протягом 12 місяців, і 30\% зазнають летальних наслідків упродовж першого року спостереження [3, 4]. Незважаючи на численні клінічні дослідження для отримання оптимальних протоколів діагностики та лікування ГСН, наші досягнення незначно покращили стан проблеми, спираючись більше на експертну думку, ніж на надійну доказову базу [1, 4, 5]. Успішне лікування пацієнтів із будь-яким гострим станом потребує ранньої діагностики, виявлення причин розвитку та своєчасного впровадження ефективного лікування - всі ці фактори пов'язані з швидкою та якісною клінічною оцінкою статусу хворого [8].

ГСН визначається як раптове виникнення або гостре погіршення симптомів та ознак серцевої недостатності, пов'язане з підвищенням плазмових рівнів натрій-уретичного пептиду $[4,6]$. Однак реєструються значні діагностичні розбіжності при зіставленні традиційних клінічних ознак та рівнів біохімічних показників, що затримує діагностику та лікування. Ультразвукова діагностика (УЗД) є доступним методом оцінки анатомічних і функціональних змін стану пацієнтів 3 ГСН, який при своєчасному проведенні може покращити якість лікування та наслідки захворювання.

Особливий інтерес становлять гемодинамічно нестабільні пацієнти з ГСН, яких госпіталізують у відділення реанімації та інтенсивної терапії (ВРIT). Ургент- не проведення УЗД серця в ВРІТ покращує результати діагностики та лікування. Цілеспрямована ехокардіографія (ЕхоКГ) у ВРІТ може бути проведена лікарямианестезіологами у ліжка хворого, що значно прискорює отримання додаткової діагностичної інформації. Навіть досвідчений лікар УЗД, з високим рівнем знань і багаторічним досвідом, має зосередитися на вирішенні нагальної потреби та провести цілеспрямоване обстеження. ЕхоКГ при ГСН використовується для підтвердження діагнозу, виявлення основних потенціальних причин, оцінки патофізіологічних змін і результатів впровадженого лікування. ЕхоКГ-дослідження також можна використовувати в рентген-операційних і при проведенні відкритих кардіохірургічних втручань.

Мета дослідження - виявлення основних причин гострої серцевої недостатності за допомогою ехокардіологічного дослідження серця.

Портативність, швидкість отримання діагностичної інформації, простота використання, відносно низька собівартість і розуміння того, що ЕхоКГ є додатковим методом діагностики до фізикального обстеження основні переваги метода.

Цілеспрямована ЕхоКГ може проводитись додатково при оцінці цілеспрямованої терапії у гемодинамічно нестабільних пацієнтів [11]. Іншої перевагою цього методу є можливість проведення серійного дослідження для визначення «відповіді» на втручання та корекції терапії [13]. Важливо розуміти, що результати цілеспрямованої ЕхоКГ завжди повинні порівнюватися 3 клінічними даними про гемодинамічний (артеріальний тиск, центральний венозний тиск, використання вазопресорів/ інотропних препаратів, параметри вентиляції, діурез тощо) та респіраторний статус пацієнта (рентгенографія органів грудної клітки, артеріальна та венозна сатурація, кислотно-лужна рівновага тощо). 
Цілеспрямована ЕхоКГ відрізняється від комплексного ЕхоКГ-дослідження, яке проводять кваліфіковані, досвідчені та сертифіковані спеціалісти [3, 5, 9]. Комплексна ЕхоКГ виходить за рамки знань новачків, які будуть використовувати лише кілька ЕхоКГ-позицій. Головним завданням для лікарів у ВРІТ є знання їх (вузької) сфери компетенції при використанні трансторакальної ехокардіографії в умовах BPIT. Сучасні практики здатні вимірювати ще низку параметрів, призначених для оцінки багатьох додаткових аспектів серцевої структури, та функції, що потребує більше часу, додаткових позицій, додаткових інструментів (внутрішньовенний контраст, маневри), а також передбачає більш високий рівень кваліфікації та підготовки в процесі отримання та інтерпретації зображень.

Експертний круглий стіл на чолі з Європейським товариством інтенсивної медицини нещодавно розробив міжнародну консенсусну заяву щодо основних принципів підготовки та акредитації лікарів-анестезіологів, які були широко прийняті [3]. Раніше викладені заяви [4] Канадського товариства ехокардіографії [13] та Американського товариства ехокардіографії [11] також стосувались аспектів навчання лікарів-інтенсивістів. Цілеспрямована ЕхоКГ часто виконується лікарями, які не навчаються отриманню та інтерпретації комплексної ехокардіограми, а також мають різний рівень кваліфікації та різний клінічний досвід. Для цих лікарів розроблено протоколи та основні принципи цілеспрямованої ехокардіографії у ВРІТ [14].

Показання. Цілеспрямована ЕхоКГ відрізняється від стандартної методики ЕхоКГ жорстко регламентованим підходом. Основним напрямом дослідження стає швидка диференційна діагностика причин гемодинамічної нестабільності. Показаннями для проведення цілеспрямованої ЕхоКГ є гемодинамічна нестабільність, шок, електромеханічна дисоціація та гостра дихальна недостатність [14].

Диференціальні діагностичні категорії для гемодинамічної нестабільності можна запам'ятати, використовуючи мнемонічний «SHOCK» (для септичних (Septic), гіповолемічних (Hypovolemic), обструктивних (Obstructive) і кардіогенних (Cardiogenic) шоків та їх комбінацій (other Kinds of shock)). "S" означає широку категорію септичного шоку через інфекцію або подібний дистрибутивний шок від неінфекційних причин. Гіповолемія $(\mathrm{H})$ виявляється змінами діаметра нижньої порожнистої вени та малими, ненавантаженими шлуночками. Обструктивний шок $(\mathrm{O})$ найчастіше виникає через тампонаду перикарда або емболію легеневої артерії, яка проявляється по-різному. Кардіогенний шок (С) зазвичай характеризується розширеними порожнинами шлуночків та/або зниженням фракції викиду чи значною клапанною дисфункцією, що визначається за допомогою кольорового допплера [5]. Коли клінічна картина і цілеспрямована ЕхоКГ чітко не вписуються в одну із цих основних категорій, слід ураховувати інші можливості - "К” («комбінації» або інші «види» шокових станів): шок може бути зумовлений комбінацією зазначених вище етіологічних захворювань і значно рідше - через інші захворювання (надниркова недостатність, нейрогенний шок тощо).

Метою цілеспрямованої ЕхоКГ є виявлення причини гемодинамічної нестабільності. Для досягнення цього конкретними цілями є систематична оцінка: 1) систолічної функції лівого шлуночка (ЛШ) (кардіогенна), 2) розмір і функція правого шлуночка (ПШ) (гіповолемія, обструкція, кардіогенність), 3) перикардіальний випіт, потенційні ознаки гемодинамічної обструкції, 4) розмір і розтягнення нижньої порожнистої вени (НПВ) для оцінки об’ємного статусу (гіповолемія) [14].

При проведенні цілеспрямованої ЕхоКГ слід відзначати наявність додаткових аномалій. Зокрема, при виявленні значних аномалій клапанів, аномалій руху стінки шлуночків, аневризми ЛШ, гіпертрофії ПШ, внутрішньосерцевих мас (вегетацій), тромбу, діастолічної дисфункції або розширеної висхідної аорти з високим ризиком розшарування слід проводити комплексне ЕхоКГ-дослідження.

Інтерпретація. Цілеспрямована ЕхоКГ завжди повинна оцінюватися в контексті гемодинамічного стану пацієнта та іншої клінічно значущої інформації. Відповідно, цілеспрямована ЕхоКГ не є анатомічним дослідженням, це фізіологічне дослідження або гемодинамічна оцінка стану хворого.

Септичний або дистрибутивний шок. На ранніх стадіях реєструються ознаки гіпердинамії ЛШ, зменшені або нормальні розміри нижньої порожнистої вени з індексом ii спадіння $>50 \%$, оскільки септичний шок часто асоціюється з гіповолемією. Більш виражений дистрибутивний шок може характеризуватися порушенням функції ЛШ. Найчастіше септичний шок у практиці кардіоанестезіолога реєструється при інфекційному ендокардиті. Основними ехокардіологічними знахідками при цій патології є: виникнення на ендотелії вегетацій, розриви стулок клапанів і їх руйнування; обрив хорд атріовентрикулярних клапанів; перфорація стулок; недостатність клапанів; внутрішньосерцеві абсцеси [13] (рис. 1).

Гіповолемічний шок проявляється малими розмірами шлуночків, іноді «облітерацією порожнини» через невеликий і гіпердинамічний лівий шлуночок та зменшені розміри нижньої порожнистої вени з широким діапазоном іiї спадіння $>50 \%$ на вдиху при самостійному диханні пацієнта. Якщо пацієнт знаходиться на штучній вентиляції в режимі вентиляції за тиском, то зміна діаметра нижньої порожнистої вени (НПВ) пов'язана з водним навантаженням. Варіація більш ніж на $12 \%$ (різниця між максимальним діаметром НПВ та мінімальним діаметром НПВ, розділеним на максимальний діаметр НПВ) свідчить про те, що серцевий викид може істотно збільшитися після об’ємної 
a)

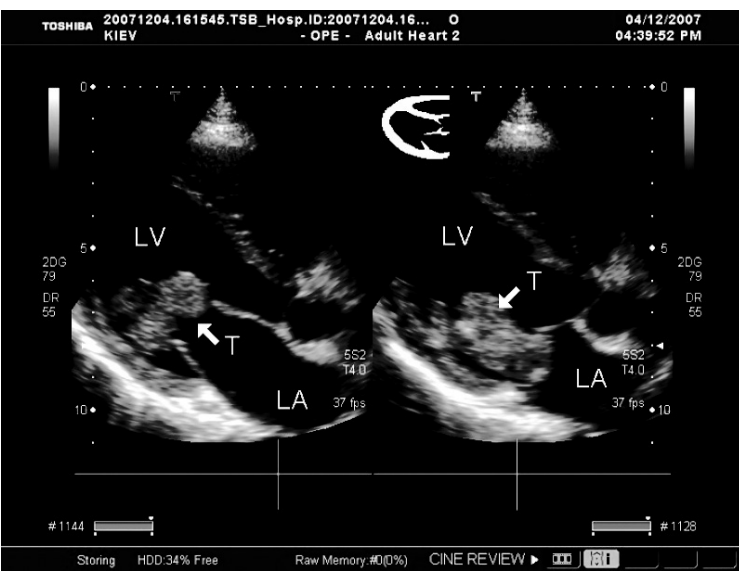

б)

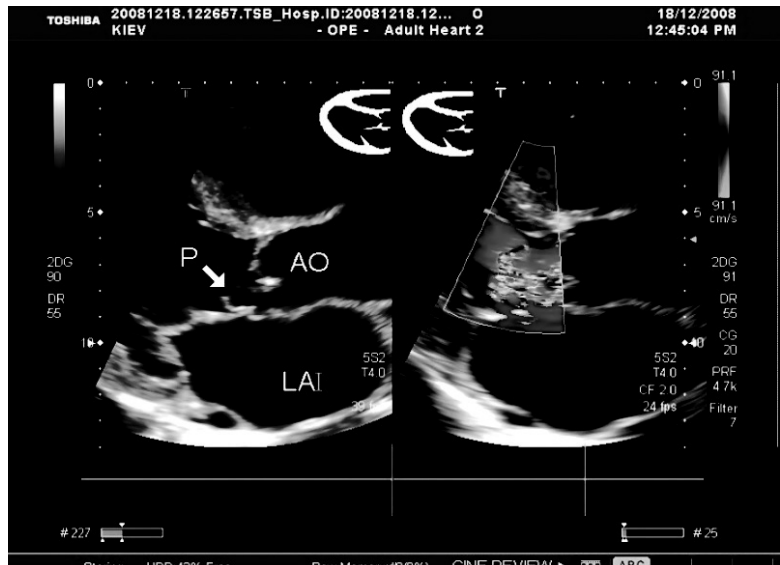

Рис. 1: а) гігантські вегетації на стулках мітрального клапана; б) перфорація стулки аортального клапана

інфузії. Питання про проведення водного навантаження вирішується в сукупності з клінічними та лабораторними даними, цілеспрямована ЕхоКГ лише доповнює інші клінічні дослідження. У пацієнтів, чутливих до об'ємного навантаження, реєструється збільшення серцевого викиду на $\geq 15 \%$ [14].

Обструктивний шок, що виник як результат тампонади серця, характеризується значною кількістю випоту в порожнині перикарда зі спадінням стінок правого передсердя та ПШ у діастолу. Також реєструється затримка діастолічної релаксації ПШ. Ці дані свідчать про збільшення тиску в порожнині перикарда [2]. НПВ розширюється, що вказує на збільшення тиску в правих відділах серця. При великій кількості випоту серце може вільно рухатися в порожнині перикарда («плаваюче серце»). Кількість перикардіального випоту не завжди корелює з клінічними проявами тампонади серця. Тампонада серця - клінічний, а не ехокардіографічний діагноз [2] (рис. 2).

Обструктивний шок при гострій тромбоемболії легеневої артерії проявляється розширенням ПШ та збільшенням співвідношення діаметрів ПШ/ЛШ > 1:1, зменшенням скорочувальної функції правого шлуночка [16]. Коефіцієнт співвідношення ПШ/ЛШ $\leq 0,6$ є нормальним, співвідношення ПШ/ЛШ від 0,6 до 1,0 свідчить про помірне розширення ПШ, співвідношення ПШ/ЛШ $\geq 1,0$ свідчить про значне розширення порожнини [15] (рис. 3).

Можливою є діастолічна деформація перегородки, яка призводить до формування «D»-ознаки, що свідчить про перевантаження об'ємом або тиском. Можлива реєстрація дискінезії міжшлуночкової перегородки. ПШ значно чутливий до змін постнавантаження і може розширюватися в умовах шоку. У пацієнта з тромбоемболією легеневої артерії діагностують збільшення порожнини ПШ, гіпокінетичний рух бічної стінки та гіпердинамічну верхівку (ознака Макконнелла) (рис. 4).

За спектром вторинної трикуспідальної недостатності можна оцінити тиск в правому шлуночку за спрощеним рівнянням Бернуллі, при цьому враховується сума градієнта тиску на трикуспідальному клапані $(\Delta$ Ртк) і тиску в правому передсерді (Рпп) - Рпж $=$ a)

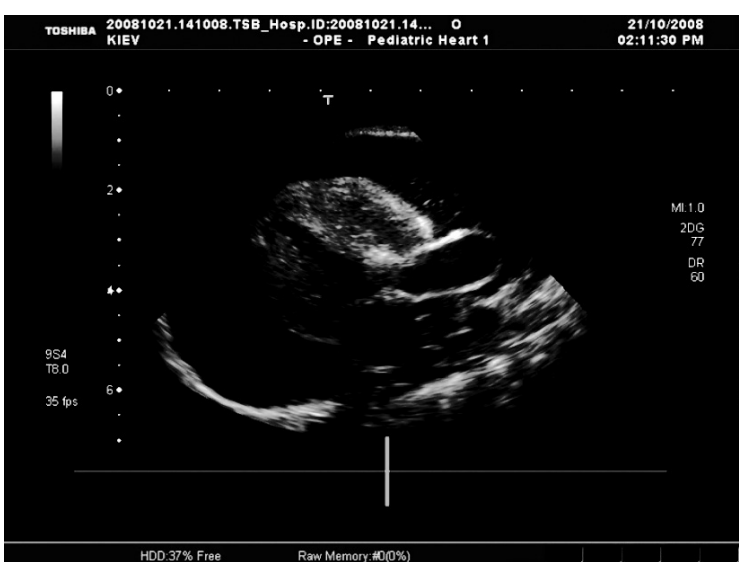

б)

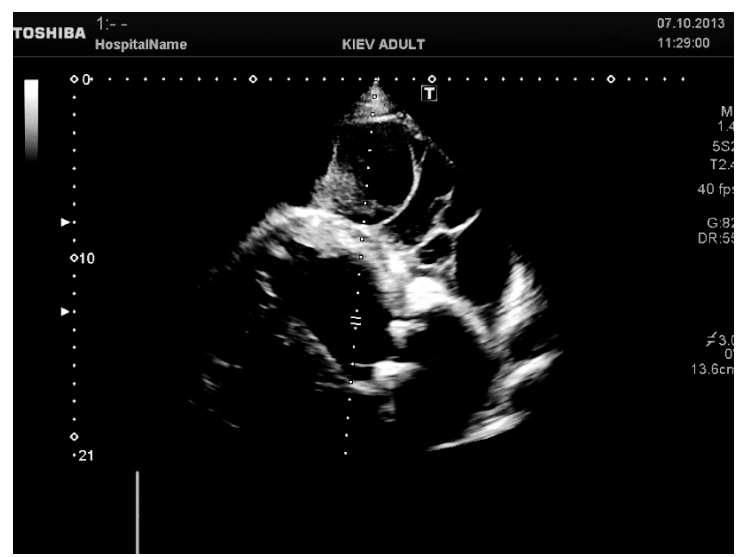

Рис. 2: а) ексудативний перикардит; «плаваюче серце»; б) ексудативний перикардит; спайки в порожнині перикарда 
a)
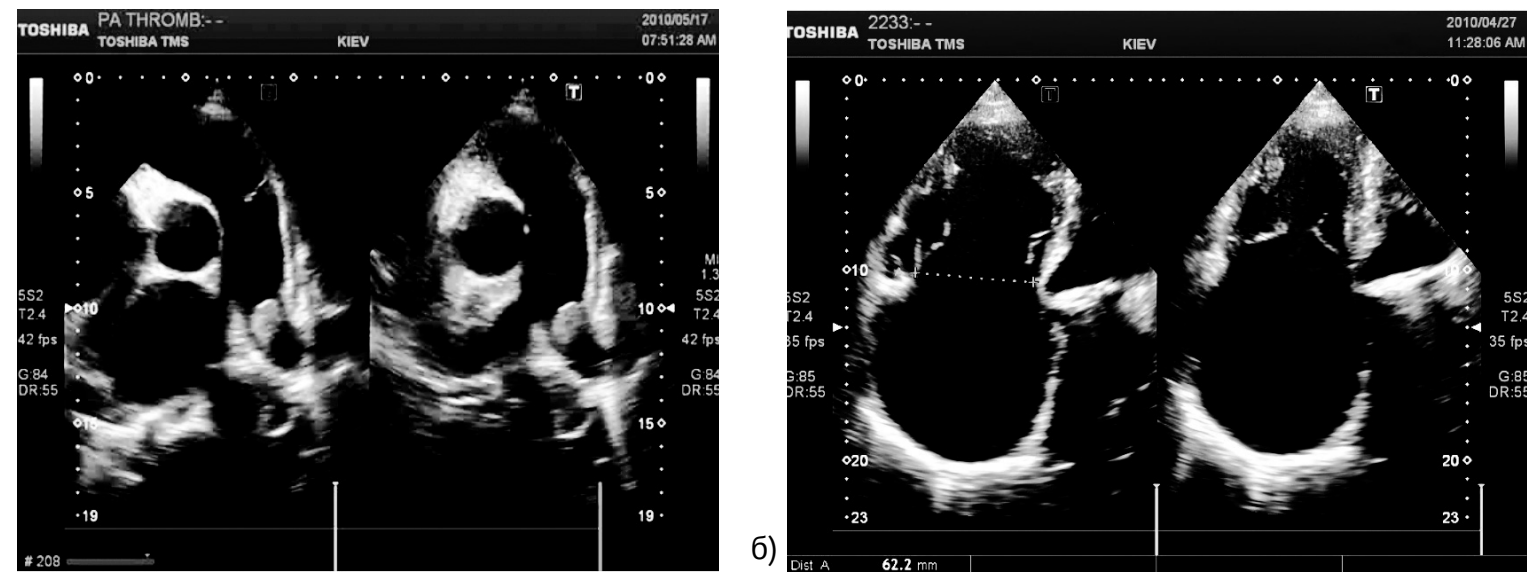

Рис. 3. а) тромбоемболія легеневої артерії, масивний тромбоз лівої гілки легеневої артерії; б) дилатація правих відділів при високій легеневій гіпертензії

a)

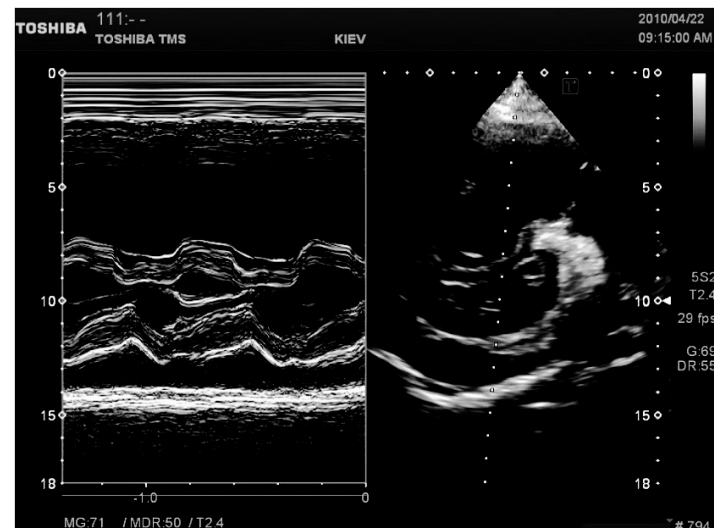

б)

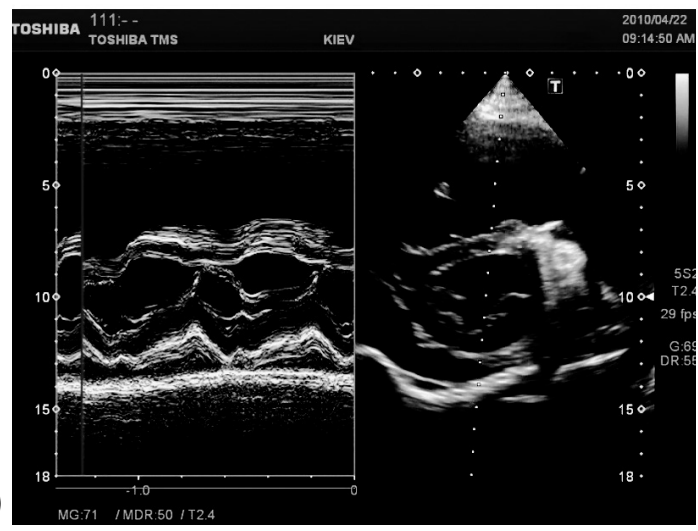

Pис. 4: a) D-подібна деформація лівого шлуночка, дискінезія міжшлуночкової перегородки; б) дилатація порожнини правого шлуночка

$\Delta$ Ртк + Рпп. Залежно від градієнта тиску між правим передсердям і правим шлуночком тиск у правому передсерді (Рпп) становить: при $\Delta \mathrm{P}<50 \mathrm{mmHg}-$ Рпп = $=5 \mathrm{mmHg}$, при $\Delta \mathrm{P} 50-80 \mathrm{mmHg}-$ Рпп $=10 \mathrm{mmHg}$, при $\Delta \mathrm{P}>80 \mathrm{mmHg}-$ Рпп $=15 \mathrm{mmHg}$ (рис. 5).

Чутливість цих знахідок для діагностики тромбоемболії легеневої артерії становить 29\% при застосуванні цілеспрямованої ЕхоКГ та 51\% - при комплексному ЕхоКГ-дослідженні [2]. Таким чином, трансторакальний ЕхоКГ-огляд недостатньо чутливий при діагностиці або виключенні емболії легеневої артерії. Цілеспрямована ЕхоКГ допомагає виявити гемодинамічні зміни у пацієнта з емболією легеневої артерії, що може бути корисним при визначенні тактики лікування. Пацієнт може мати підвищене значення індексу ПШ / ЛШ також при наявності хронічного обструктивного захворювання легень (ХОЗЛ), первинної легеневої гіпертензії та інфаркту міокарда ПШ [2].

Кардіогенний шок проявляється розширенням порожнини та/або зниженням функції ЛШ, можливим зниженням функції ПШ та розширенням НПВ [5].
Крім того, гостра клапанна регургітація може спричиняти кардіогенний шок. Кольорова допплерівська ЕхоКГ допомагає виявити клапанну регургітацію, але для цільового використання та тлумачення потрібна додаткова підготовка [3, 5]. Функція ЛШ оцінюється як «незначно знижена» або «значно зменшена» зазвичай на основі візуальної оцінки фракції викиду (фракція викиду $=($ кінцевий діастолічний об’єм - кінцевий систолічний об’єм) / кінцевий діастолічний об'єм). За допомогою цілеспрямованої ЕхоКГ функція ЛШ оцінюється як нормальна, зменшується або дуже зменшується (рис. 6). Мінімальне зменшення фракції викиду не вважається «значним», оскільки не може самостійно спровокувати кардіогенний шок. Найчастіше кардіогенний шок реєструється у пацієнтів з ішемічною хворобою серця (IXC). До ускладнень гострої стадії IXC відносять дисфункцію міокарда ЛШ і ПШ, розрив вільної стінки ЛШ (тампонада) або формування хибної аневризми, розрив міжшлуночкової перегородки, розрив папілярного м'яза з розвитком гострої мітральної недостатності, пристінковий тромбоз, перикардит. 
a)
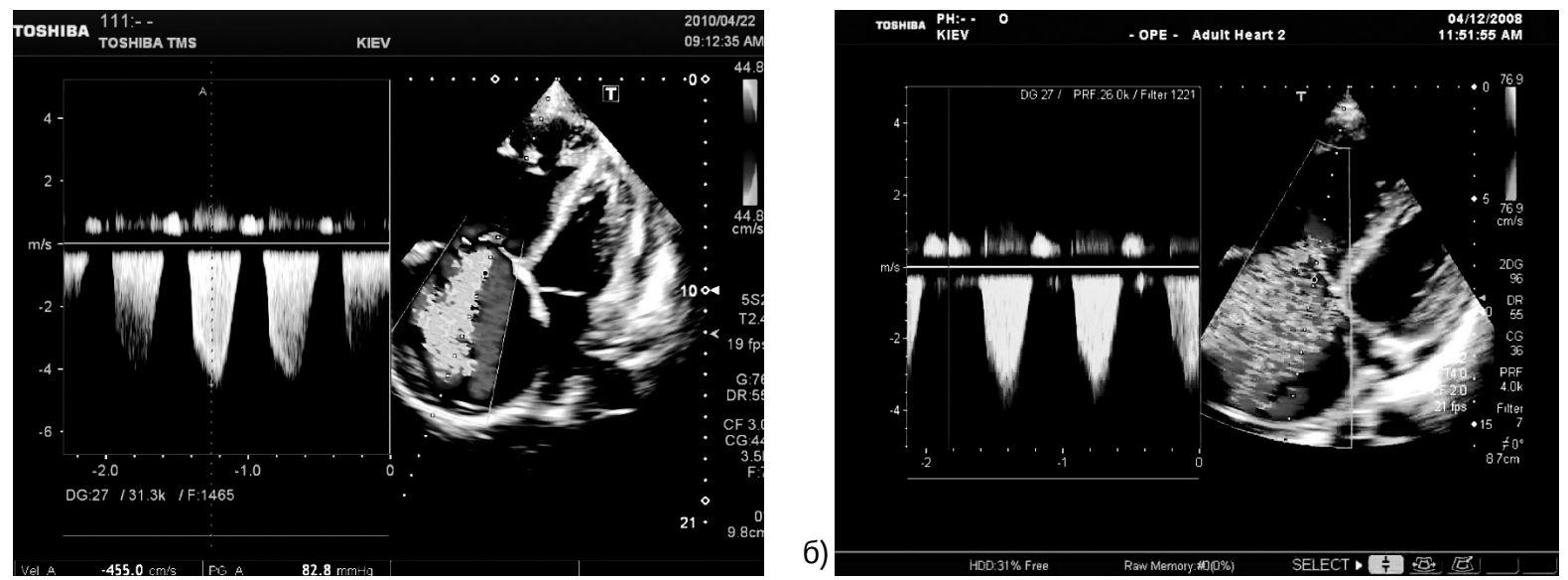

Рис. 5. а) виражена трикуспідальна недостатність; високий тиск у правому шлуночку за спектром трикуспідальної недостатності; б) високий тиск у правому передсерді за рахунок градієнта між правим передсердям і правим шлуночком

a)

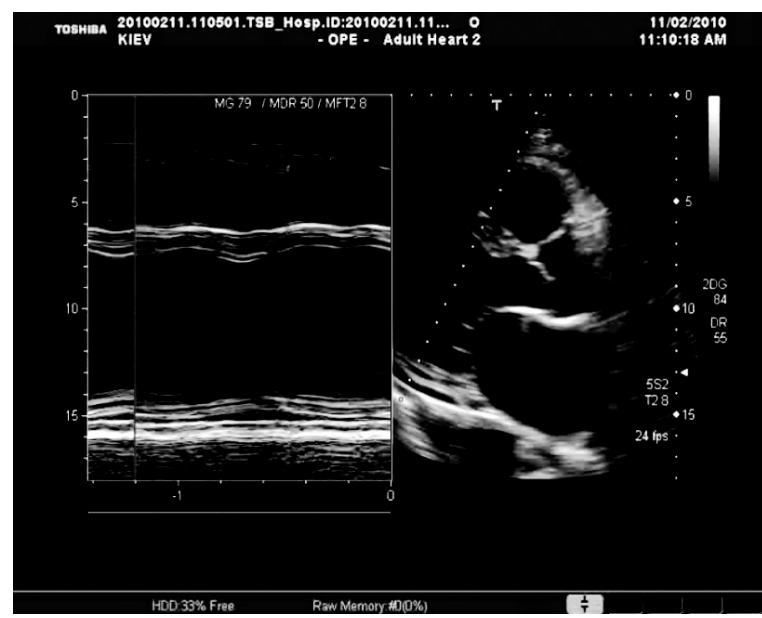

б)

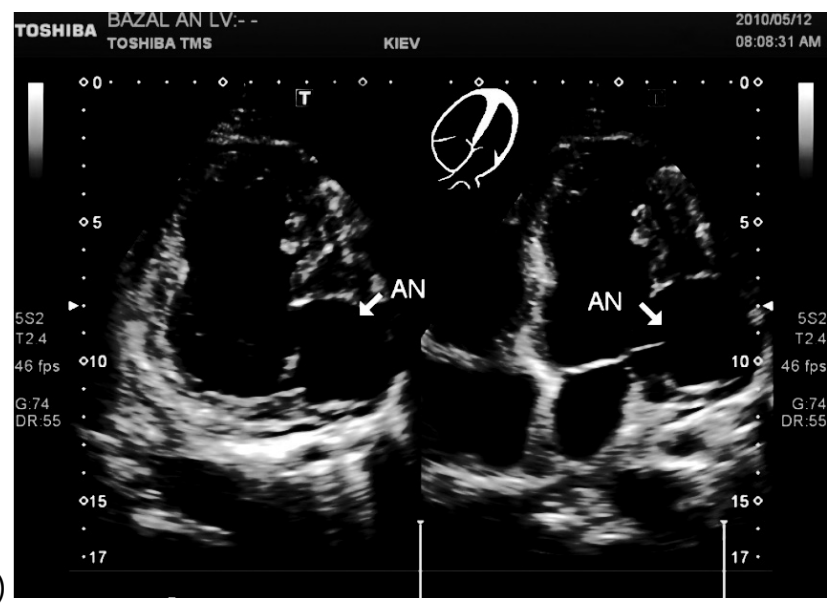

Рис. 6: а) дисфункція міокарда лівого шлуночка; інфаркт міокарда задньої стінки лівого шлуночка;

б) розрив вільної стінки лівого шлуночка; хибна аневризма

При проведенні інтерпретації отриманих даних необхідно враховувати вплив переднавантаження, тисків із боку грудної клітки та легень, постнавантаження та ефекти медичних препаратів.

Висновки. Ультразвукова діагностика невідкладних станів при гострій серцевій недостатності «біля ліжка» пацієнта стала критичною точкою для майбутнього охорони здоров'я. Незважаючи на перспективи телемедицини, значущість лабораторних біомаркерів, поширення комплексних рентгенологічних досліджень та експертний підхід до медичної допомоги, фізична присутність лікаря біля ліжка пацієнта для проведення кваліфікованої діагностики зміцнює у пацієнта довіру, підтримує відповідальність лікаря, залишаючись наріжним каменем пацієнт-орієнтованого лікування. Цілеспрямована ЕхоКГ підвищує чутливість фізикального огляду гемодинамічно нестабільного паці- єнта та сприяє ранньому виявленню причин серцевої недостатності, що, у свою чергу, забезпечує своєчасне лікування та кращі результати. Використання цілеспрямованої ЕхоКГ лікарями-інтенсивістами у ВРІT для лікування гострої серцевої недостатності зміцнює традиційну модель медичної допомоги.

\section{Література}

1. 2013 ACCF/AHA guideline for the management of heart failure: a report of the American College of Cardiology Foundation/American Heart Association task force on practice guidelines / Yancy C. W. et al. // J. Am. Coll. Cardiol. - 2013. - Vol. 62. - e147-e239.

2. Roger V. L. Epidemiology of heart failure // Circ. Res. 2013. - Vol. 113. - P. 646-659.

3. Guideline Development Group of the National Institute for Health and Care Excellence. Diagnosing and managing acute heart failure in adults: summary of NICE guidance / 
Dworzynski K., Roberts E., Ludman A. et al. // BMJ. 2014. - Vol. 349. - g5695.

4. 2016 ESC guidelines for the diagnosis and treatment of acute and chronic heart failure: the task force for the diagnosis and treatment of acute and chronic heart failure of the European Society of Cardiology (ESC). Developed with the special contribution of the Heart Failure Association (HFA) of the ESC // Ponikowski P. et al. // Eur. Heart J. 2016. - Vol. 37. - P. 2129-2200.

5. Braunwald E. Heart failure // JACC Heart Fail. - 2013. Vol. 1. - P. 1-20.

6. 2013 ACCF/AHA guideline for the management of heart failure: a report of the American College of Cardiology Foundation/American Heart Association task force on practice guidelines / Yancy C. W. et al. // Circulation. 2013. - Vol. 128. - e240-e327.

7. European Society of Cardiology - Acute Cardiovascular Care Association position paper on safe discharge of acute heart failure patients from the emergency department / Miro O. et al. // Eur. Heart J. - 2016. - Acute Cardiovasc. Care http://dx.doi.org/10.1177/ 2048872616633853

8. European Society of Cardiology - Acute Cardiovascular Care Association position paper on acute heart failure: a call for interdisciplinary care / Mueller C. et al. // Eur. Heart J. - Acute Cardiovasc. Care - 2017. - Vol. 6. - P. 81-86.

9. Recommendations on pre-hospital and early hospital management of acute heart failure: a consensus paper from the Heart Failure Association of the European Society of Cardiology, the European Society of Emergency Medicine and the Society of Academic Emergency Medicine - short version / Mebazaa, A. et al. // Eur. Heart J. - 2015. Vol. 36. - P. 1958-1966.
10. Acute heart failure syndromes: emergency department presentation, treatment, and disposition: current approaches and future aims: a scientific statement from the American Heart Association / Weintraub, N. L. et al. // Circulation - 2010. - Vol. 122. - P. 1975-1996.

11. Expert Round Table on Ultrasound in ICU: International expert statement on training standards for critical care ultrasonography // Intensive Care Med. - 2011. - Vol. 37. - P. 1077-1083.

12. American College of Chest Physicians/La Societe de Reanimation de Langue Francaise statement on competence in critical care ultrasonography / Mayo P. H., Beaulieu Y., Doelken P. et al. // Chest. - 2009. - Vol. 135. P. $1050-1060$.

13. Repesse X., Charron C., Vieillard-Baron A: Intensive care ultrasound: V. Goal-directed echocardiography // Ann Am Thorac Soc. - 2014. - Vol. 11. - P. 122-128.

14. Canadian Cardiovascular Society/Canadian Society of Echocardiography guidelines for training and maintenance of competency in adult echocardiography / Burwash I. G., Basmadjian A., Bewick D. et al. // Can J Cardiol. - 20102011. - Vol. 27. - P. 862-864.

15. The use of pocket-size imaging devices: a position statement of the European Association of Echocardiography / Sicari R., Galderisi M., Voigt J. U. et al. // Eur J Echocardiogr. - 2011. - Vol. 12. - P. 85-87.

16. Moore C. L., Copel J. A. Point-of-care ultrasonography // N Engl J Med. - 2011. - Vol. 364. - P. 749-757.

17. Solomon S. D., Saldana F. Point-of-care ultrasound in medical education - stop listening and look // N Engl J Med.-2014. - Vol. 370. - P. 1083-1085.

\title{
Using ultrasound to diagnose emergency states in acute heart failure
}

\author{
Koltunova A., Beshlyga I., Beshlyaga V. \\ National M. M. Amosov Institute of Cardiovascular Surgery National Academy of Medical Sciences of Ukraine (Kyiv)
}

Echocardiographic study is recommended for the diagnosis and assessment of urgent states in patients with acute heart failure. The development of ultrasound technology has led to the introduction of this study not only in the practice of the cardiologist, but also anesthesiologist at the critical care units. The obtained results of echocardiographic examination improve the accuracy of early diagnosis, tactics and monitoring the results of the proposed treatment in patients with acute heart failure. The use of goal-directed echocardiography by intensive care physicians for the treatment of acute heart failure strengthens the traditional model of medical care.

Key words: urgent states, acute heart failure, goal-directed echocardiography.

\section{Ультразвуковая диагностика неотложных состояний при острой сердечной недостаточности}

\author{
Колтунова А. Б., Бешляга И. В., Бешляга В. М.
}

ГУ «Национальный институт сердечно-сосудистой хирургии имени Н. М. Амосова НАМН» (Киев)

\begin{abstract}
Проведение эхокардиографического исследования все чаще рекомендуется для диагностики и оценки неотложных состояний пациентов при острой сердечной недостаточности. Развитие ультразвуковых технологий привело к внедрению этого исследования в практику не только кардиологов, но и врачей-анестезиологов в отделениях реанимации и интенсивной терапии. Результаты эхокардиографического обследования улучшают точность ранней диагностики, тактику ведения и мониторинг результатов предложенного лечения у больных с острой сердечной недостаточностью. Использование целенаправленной эхокардиографии врачами-интенсивистами для лечения острой сердечной недостаточности укрепляет традиционную модель медицинской помощи.
\end{abstract}

Ключевые слова: неотложные состояния, острая сердечная недостаточность целенаправленная эхокардиография. 